\title{
Foucault, Normativity, and Freedom: A Reappraisal
}

\author{
GIOVANNI MARIA MASCARETTI \\ University of Kurdistan Hewlêr, Kurdistan Region, Iraq
}

\begin{abstract}
The aim of this article is to contribute to the recently revived debate over the normativity of Foucault's genealogical method. More specifically, I shall respond to Fraser's charge that Foucault's rejection of humanism is unjustified because he cannot state why a totally panopticized, autonomous society would be objectionable. After dismissing a non-normative defence strategy of Foucault's work, I shall proceed as follows: firstly, I shall clarify Foucault's model of critique as a practice of problematization geared to free his addressees from their captivation to the system of truths sustaining the power mechanisms of modern biopolitics. Secondly, I shall argue that Fraser's society should be resisted because it would reproduce this regime of captivity, thereby obstructing the exercise of freedom as self-transformation. Thirdly, I shall contend that Foucault's normative orientation to a post-humanist conception of freedom as self-transformation finds a contextual, explanatory account in his attempt to revitalize the emancipatory project of Enlightenment modernity through a transformative problematization of our normative commitments. Moreover, I shall show that the standard of validity of this effort is represented by Foucault's exemplary embodiment of the critical ethos of the Enlightenment in both his style of existence and theoretical activity. Finally, the article terminates by illustrating three shortcomings of Foucault's normative approach.
\end{abstract}

Keywords: Foucault; normativity; regime of truth; Enlightenment; freedom; critique

\section{INTRODUCTION}

The question of the normative framework characterizing Foucault's genealogical critique of modernity has been the focus of a long and vexed debate. Since the 1980s, early critics accused him of lacking the normative resources necessary to justify his call for critique and resistance against modern forms of power. Although he obliquely addressed similar remarks in his later works, Foucault could never engage in a more direct confrontation due to his death in 1984. As a result, the defence of his enterprise passed on in the hands of his advocates, whose responses had the initial merit of emphasising the tendentious 
nature of the allegations levelled at him. ${ }^{1}$ Subsequent contributions, though, took the shape of a confrontational dialogue, with the consequence that the debate surrounding Foucault and normativity lost much of its pull and faded somewhat into the background.

With the English publication of his later articles, interviews, and Collège de France lectures, however, a number of scholars have recently revitalized this debate by shifting the latter towards an investigation of the stance Foucault endorses in relation to the question of the normativity of critique and resistance. Their interpretive proposals are wide-ranging, and I certainly do not pretend to examine all of them. ${ }^{2}$ Still, here I shall discuss some prominent readings which follow two key strategies. The first strategy identifies the distinctive feature of Foucault's genealogy in its allegedly non-normative and descriptive nature, whereby his detractors would erroneously condemn Foucault for being unable to secure a project he was never engaged in. The second strategy, instead, argues that Foucault does make normative claims, but the specific kind of normativity he opts for cannot be reconciled with the requirements put forward by his critics. My goal will be to contribute to this second line of argument by elaborating an alternative account of the normative dimension of Foucault's thought, which I shall frame as a response to the charge of genetic fallacy raised at him by Nancy Fraser: without a post-humanist paradigm of freedom, Foucault cannot make the case for his normative rejection of the hypothetical picture of a fully panopticized society where humanist ideals would be realized.

To this end, I shall divide my paper into four sections. Section 1 will present Fraser's reasoning and illustrate the shortcomings marking a non-normative defence of Foucault. Laying the groundwork for a correct appraisal of the interpretative-evaluative orientation underlying his project, section 2 will clarify Foucault's largely implicit model of critique. More specifically, I shall maintain that the latter consists in a practice of problematization geared to emancipate us from our captivation to the 'regime of truth' shaping our experience, i.e., the system of intelligibility for thought and action resulting from the convergence of the discourses of humanism with the governmental mechanisms of modern biopolitics. Accordingly, in section 3 I shall be able to argue that, for Foucault, Fraser's picture of an autonomous society should be resisted because it would ingrain our subjection to this very same regime, thereby impeding us from exercising our capacity for freedom as a practice of self-transformation. While he rejects the demand for a discursive justification of such a post-humanist conception of freedom, I shall show that Foucault's later writings on the Enlightenment can be taken to supply a context-sensitive, explanatory account of his normative stance. In a nutshell, submitting current normative commitments to a radical problematization aimed at their transformation is the best way for him to be true to the emancipatory ideals of Enlightenment modernity. In the absence of further grounds, then, I shall claim that one can find the ultimate standard for assessing the credibility of Foucault's normative position in his exemplary embodiment of the critical ethos of the

\footnotetext{
${ }^{1}$ Michael Kelly, "Introduction," in Critique and Power: Recasting the Foucault/Habermas Debate, ed. Michael Kelly (1994).

${ }^{2}$ For a quite exhaustive overview, see Christopher R. Mayes, “Revisiting Foucault's 'Normative Confusions': Surveying the Debate Since the Collège de France Lectures," Philosophy Compass 10:12 (2015), 841-855.
} 
Enlightenment. That is reflected by Foucault's experimental and militant life on the one hand, and, on the other, by the neutralization of the epistemological framework of humanism, which is accomplished through his renewed formulation of the concepts of power, knowledge, and the subject. Finally, section 4 will conclude by pointing out three limitations marking Foucault's normative strategy.

\section{SETTING UP THE PROBLEM OF NORMATIVITY}

In a 1985 contribution to the Foucault/Habermas debate, Nancy Fraser formulates a very sophisticated critique of Foucault which casts doubt on the normative validity of his genealogical method. To begin with, Fraser analyses the accusations Habermas moves against Foucault. In The Philosophical Discourse of Modernity, Habermas argues that Foucault's genealogical critique of modernity is premised upon a cryptic normative bias, for which he cannot give any compelling justification due to his functional reduction of validity claims to effects of power. ${ }^{3}$ Consequently, on Habermas' view, Foucault is guilty of performative contradiction: by discarding the values of truth, rationality, and autonomy implicit in his unacknowledged commitment to "a picture of undamaged intersubjectivity" ${ }^{4}$, Foucault undercuts the very normative grounds of his own critique and ends up advocating a radical and total break with Enlightenment modernity. As Fraser correctly notes, Habermas' reading is not only misguided in important respects. ${ }^{5}$ His interpretation also misses the real target of Foucault's critique. Contrary to what Habermas maintains, Foucault's genealogy amounts to a rejection not of the Enlightenment but, rather, of humanism. Indeed, for Foucault, Enlightenment modernity and humanism stand "in a state of tension rather than identity". ${ }^{6}$ However, instead of explaining on what grounds he rejects humanism, Fraser claims that Foucault conflates three different arguments against humanism: a conceptual, a strategic, and a normative one. For my purposes here, I shall focus on the last one, which considers humanism to be intrinsically undesirable. In order to support her reading, Fraser invites us to consider the following hypothesis:

Imagine a perfected disciplinary society in which normalizing power has become so omnipresent, $[\ldots]$ so $[\ldots]$ interiorized, $[\ldots]$ that $[. .$.$] hierarchical, asymmetrical domina-$ tion of some persons by others would have become superfluous. The members of this society would [...] be autonomous. [...] But, it is claimed, this would not be freedom. ${ }^{7}$

\footnotetext{
${ }^{3}$ Jürgen Habermas, The Philosophical Discourse of Modernity, trans. Frederick Lawrence (1987), 275-276.

${ }^{4}$ Ibid., 337.

${ }^{5}$ Foucault denies that "games of truth are just concealed power relations". Rather, his problem has always been to understand "how truth games are set up and how they are connected with power relations", see Michel Foucault, "The Ethics of the Concern for Self as a Practice of Freedom," in Ethics, Subjectivity, and Truth: Essential Works of Foucault, Volume 1, ed. Paul Rabinow, trans. Robert Hurley et al. (1997), 296.

${ }^{6}$ Ibid., 314.

${ }^{7}$ Nancy Fraser, "Michel Foucault: A 'Young Conservative'?," in Critique and Power: Recasting the Foucault/Habermas Debate, ed. Michael Kelly (1994), 202-203.
} 
What this picture of total panopticism hints at is a surreptitious connivance of humanism with disciplinary power, whereby the appeal to the humanist ideals of autonomy and reciprocity marking Habermas' theory would sanction his inability to shatter the dominance of its regime. Still, for Fraser, there is a promising move a Habermasian humanist could make in order to reply to this criticism. A Habermasian humanist could simply say " 'if that's discipline, I am for it'", because "there is no good reason to oppose such a society". The latter appears to be unacceptable because Foucault portrays it as "the outcome of a historical process of hierarchical, asymmetrical coercion wherein people have been [...] 'bred' to autonomy". ${ }^{8}$ But, as Fraser continues, Foucault's argument invites genetic fallacy, since it draws normatively ambitious conclusions from empirically descriptive insights into our own history, thus generating what she elsewhere calls "normative confusions". ${ }^{9}$ In order to remedy these confusions, Foucault should have provided us with "a new paradigm of freedom" 10 separate from the vocabulary of humanism, which would have enabled him to clarify what is obnoxious in a fully panopticized society. Since in her view that is not the case, Fraser concludes that Foucault's normative rejection of humanism is unwarranted. ${ }^{11}$ To put it briefly, being unable to account for the shift from his suspension of the liberal question of the legitimacy of modern power to his call for resistance against biopower, Foucault's work lacks "an adequate normative perspective"12, a defect that stands in contrast with the richness of his analyses of power in modern society. Now, is there a way to reply to this allegation? A distinctive strategy of response consists in defending an interpretation of Foucault as a non-normative thinker. Below, I shall examine two versions of such a reading and clarify the reasons why their explanations remain unconvincing.

The first version can be found in Koopman's book Genealogy as Critique. ${ }^{13}$ Contra Fraser, Koopman claims that Foucault's genealogy is meant not to make definitive judgments

\footnotetext{
${ }^{8}$ Ibid., 203-204.

${ }^{9}$ Nancy Fraser, "Foucault on Modern Power: Empirical Insights and Normative Confusions," in Unruly Practices: Power, Discourse and Gender in Contemporary Social Theory (1989).

${ }^{10}$ Fraser, “Michel Foucault: A 'Young Conservative'?," 205.

${ }^{11}$ Fraser draws similar conclusions in her 1983 article entitled "Foucault's Body Language: A Posthumanist Political Rhetoric". The polemical target of this essay is the new vocabulary for social criticism Foucault hints at by the reference he makes to the emancipatory force of "bodies and pleasures" in the first volume of The History of Sexuality. For Fraser, such a new language is meant to replace the humanist paradigm as the normative basis of Foucault's critique of the techniques of domination marking our modern social world. However, Foucault's language of "bodies and pleasures" presents the same shortcomings he detects in the humanist rhetoric: indeed, "it seems to involve a retreat from antifoundationalism and a turn to a new metaphysics - one of bodies - and it may be no less subject to co-optation and mystification than Foucault claims humanist critique has been", Nancy Fraser, "Foucault's Body Language: A Posthumanist Political Rhetoric," in Unruly Practices: Power, Discourse and Gender in Contemporary Social Theory (1989), 59. According to Fraser, therefore, Foucault's repudiation of humanism remains questionable and largely unpersuasive. Given the intricacy of Foucault's idea of the body, an adequate examination of Fraser's uncharitable reading would demand much more space than I have at my disposal here. Consequently, I shall leave it aside and keep on focalizing my attention on Fraser's 1985 essay, whose discussion of the problematic of freedom in Foucault's work is also more germane to my overall purposes.

${ }^{12}$ Fraser, "Foucault on Modern Power", 33.
} 
about the wrongness of our practices and forms of self-constitution, but rather to expose their dangerous nature through a critical problematization of the power-laden processes that have enabled their emergence. As a result, for Koopman, Fraser's argument is misleading: Foucault's genealogy is not fallacious because it does not amount to the robust kind of genetic reasoning she attacks. Such an interpretation does not lack textual support. Most notably, expressing his view on Nietzsche's propensity to conflate genesis and validity, in a later interview Foucault states: "I think there is no relation between genesis and validity". ${ }^{14}$ Yet, it is my contention that Koopman overstretches Foucault's position. Although he thinks it can be integrated with the resources for normative reconstruction provided by Habermas and pragmatism, Koopman indeed maintains that Foucault' genealogy would offer a description of the problematizations at the basis of the historical appearance of certain practices fraught with dangers "without making any normative claims about these practices". ${ }^{15}$ Now, the strict line of demarcation Koopman draws between Foucault's genealogical approach and normativity seems hardly tenable. To show why this is the case, I shall start by considering the following passage:

I would like to do the genealogy of problems, of problématiques. My point is not that everything is bad, but that everything is dangerous, which is not exactly the same as bad. If everything is dangerous, then we always have something to do. So my position leads not to apathy but to a hyper- and pessimistic activism. I think that the ethico-political choice we have to make every day is to determine which is the main danger. Take as an example Robert Castel's analysis of the history of the antipsychiatry movement [La Gestion des risques]. I agree completely with what Castel says, but that does not mean, as some people suppose, that the mental hospitals were better than antipsychiatry; that does not mean that we were not right to criticize those mental hospitals. I think it was good to do that, because they were the danger. And now it's quite clear that the danger has changed. ${ }^{16}$

On my view, what Foucault means here is that the genealogical examination of how a set of given practices "could [...] be valid, at a certain moment, in a certain context"17 does involve a kind of normative evaluation, which he articulates in terms of the dangerousness derived from the structural circularity between validity and relations of power.

There are at least two reasons for favouring this line of argument: first, it coheres well with the rhetorical inflection of Foucault's work as well as with the political and

\footnotetext{
${ }^{13}$ Colin Koopman, Genealogy as Critique. Foucault and the Problems of Modernity (2013), 88-90.

${ }^{14}$ Michel Foucault, "Ethics and Politics," unedited and unpublished full interview with Paul Rabinow, Richard Rorty, Martin Jay, Leo Löwenthal, and Charles Taylor held at the University of California at Berkeley in April 1983. For a complete transcription, see Michel Foucault, "Discussion with Michel Foucault", in IMEC/Fonds Michel Foucault, D 250(8). Excerpts of this interview were later published in Michel Foucault, "Politics and Ethics: An Interview," in The Foucault Reader, ed. Paul Rabinow (1984).

${ }^{15}$ Koopman, Genealogy as Critique, 92, emphasis added.

${ }^{16}$ Michel Foucault, "On the Genealogy of Ethics: An Overview of Work in Progress," in Ethics, Subjectivity, and Truth: Essential Works of Foucault, Volume 1, ed. Paul Rabinow, trans. Robert Hurley et al. (1997), 256, emphasis added.

${ }^{17}$ Foucault, "Ethics and Politics".
} 
epistemological primacy he allocates to resistance in his analysis of modern power. ${ }^{18}$ In a 1978 interview, for instance, Foucault describes his project as being aimed at "deciphering a layer of reality in such a way that [...] the lines of fragility come forth; [...]. It is a reality of possible struggles that I wish to bring to light". ${ }^{19}$ Secondly, whereas I agree with Koopman that Foucault's "distinction between problematic indeterminacy and determinate wrongness" 20 enables him to avoid the dead end of moralism, I shall insist that "the very notion of danger is itself value-laden". ${ }^{21}$ As the passage above suggests, what motivates Foucault's genealogical investigations of the dangers embedded in certain historical practices is the attempt to illuminate their bad uses and their adverse implications for our contemporary life. Moreover, even if it were abnormative, the category of dangerousness seems to involve not only a normative call for attention, but also a recommendation for some kind of reflexive intervention, as attested by Foucault's allusion to his own hyperand pessimistic activism. Consequently, pace Koopman, speaking about dangers does not relieve one of addressing the problem of normativity. Rather, it leaves us with a pressing series of questions: why is power "dangerous'? For whom? And what is the normative orientation enabling Foucault's own talk about dangers?

As mentioned above, however, Koopman is not the sole scholar to divorce Foucault's genealogical method from normativity. Mark Kelly has recently argued that what distinguishes Foucault's work is his rejection of any normative vision that would prescribe what and how one should think and act. In this respect, for Kelly, Foucault endorses a nonnormative modality of critique that is both "atheoretical" and unpolitical: not only does he abstain from totalizing and systematic theorizing, but he also discards politics in the form of "'party's politics' and statecraft". Foucault, therefore, would engage in a type of critique whose role is "simply to analyse things in order to undermine them". ${ }^{22}$ Notwithstanding the inconclusive reasons he provides to defend the preferability of this approach over normative political theory ${ }^{23}$, here I would like to call into question the non-normative reading of Foucault's thought Kelly proposes. To begin with, whereas Kelly maintains that Foucault's analyses are purely descriptive and his vocabulary is neutral, one can find several passages where Foucault makes explicit his valorisation of difference and emancipatory transformation, like the following one:

\footnotetext{
${ }^{18}$ See Michel Foucault, "The Subject and Power," in Power: Essential Works of Foucault, Volume 3, ed. James D. Faubion, trans. Robert Hurley et al. (2000), 329. See also Michel Foucault, "The Analytic Philosophy of Politics," trans. Giovanni Maria Mascaretti, Foucault Studies 24 (2018), 192.

${ }^{19}$ Michel Foucault, "Clarifications on the Question of Power," in Foucault Live: Collected Interviews, 1966-1984, ed. Sylvère Lotringer (1996), 261.

${ }^{20}$ Colin Koopman, “Genealogy, Methodology, \& Normativity beyond Transcendentality: Replies to Amy Allen, Eduardo Mendieta, \& Kevin Olson," Foucault Studies 18 (2014), 269.

${ }^{21}$ Richard J. Bernstein, "Foucault: Critique as Philosophical Ethos," in Critique and Power: Recasting the Foucault/Habermas Debate, ed. Michael Kelly (1994), 227.

${ }^{22}$ Mark G. E. Kelly, For Foucault: Against Normative Political Theory (2018), 9-11.

${ }^{23}$ For an illuminating piece, see Frieder Vogelmann's review of For Foucault: Against Normative Political Theory, by Mark G. E. Kelly, Notre Dame Philosophical Reviews. An Electronic Journal, 2018 (accessed October 5, 2018).
} 
We must fight against the impoverishment of the relational fabric. We must secure recognition for relations of provisional coexistence, adoption... ${ }^{24}$

The normative connotation of similar passages seems unmistakable. Nevertheless, Kelly can rebut that "there is no need to assert normatively that we should be on the side of resistance, since [...] we are essentially resistant entities", whose "nature is precisely to defy any attempt to ascribe to us any specific natural qualities". ${ }^{25}$ What I take Kelly to mean is that the difference Foucault's draws between resistance and power does not rest upon universal standards for judgment, according to which resistance and power would stand for the good and bad respectively. After all, resistance and power are normatively ambivalent phenomena, where resistance should be construed just as "counter-power". Rather, what demarcates resistance from power is that resistance does not call for the articulation of any norm. As Kelly puts it, "social movements do require norms [...] to the extent that they have power relations within them, and are not purely resistant" ${ }^{26}$ Now, what is the rationale behind this normative division? Kelly's answer heavily relies on Patton's account of Foucault's subject of power. According to the latter, "resistance is an effect of human freedom", whereby "in the attempt to exercise their capacity for autonomous action, those subject to relations of domination will inevitably be led to oppose them" ${ }^{27}$ On Patton's view, then, resistance would be guaranteed by our force as living entities, namely as conscious and self-conscious agents endowed with the power (in the Latin sense of the word "potere") to freely act otherwise when power is exerted over us in the form of domination.

As Schubert clarifies, however, Patton's interpretation amounts to an "ontological shortcut" 28 , which assumes that the general and minimal definition of human beings' free capacity for action can "automatically" solve, as it were, the socio-theoretically complex and specific problem of the historical emergence of freedom as critical resistance against the modern regimes of subjec(tiva)tion. To the contrary, Patton's socio-ontological account of human agency can only demonstrate the possibility of resistance in light of the essential freedom of individual agents to act otherwise within the strategic field of the existing governmental technologies of power ${ }^{29}$, while it fails to explain how such freedom translates into actual and singular practices of resistance geared to transform the dominant modes of social identification. To state it briefly, pace Kelly, we are essentially free in a minimal sense, but not essentially resistive. Rather, the actualization of resistance depends upon a certain "decision-making will not to be governed"30 like that and at such a

\footnotetext{
${ }^{24}$ Michel Foucault, “The Social Triumph of the Sexual Will," in Ethics, Subjectivity, and Truth: Essential Works of Foucault, Volume 1, ed. Paul Rabinow, trans. Robert Hurley et al. (1997), 158, translation amended, emphasis added.

${ }^{25}$ Kelly, For Foucault, 154.

26 Ibid., 124.

27 Paul Patton, "Foucault's Subject of Power," Political Theory Newsletter 11 (1994), 69.

${ }^{28}$ Karsten Schubert, Freiheit als Kritik. Sozialphilosophie nach Foucault (2018), 59.

${ }^{29}$ Ibid., 151.

${ }^{30}$ Michel Foucault, "What is Critique?," in The Politics of Truth, ed. S. Lotringer, trans. L. Hochroth and C. Porter (2007), 74.
} 
price, which Foucault places at the root of the critical attitude questioning the modern arts of government. But doesn't the concept of a decision-making will entail a reference to the normative interests behind such a choice? And doesn't the specification "at such a price" hint at the "deep malaise" 31 produced by abusive techniques of government that can no longer be accepted? The normative implications of these questions go missing in Kelly's reading. Assuming the equivalence between normativity and prescription as the unquestioned premise of his argument, in fact, Kelly insists on claiming that the basis of Foucault's opposition to power is not the commitment to some normative values. Foucault's critique, instead, should be better understood as a descriptive analysis aimed at unveiling the "hypocrisy" of power, namely how power has to substantially conceal itself in order to be "tolerable". ${ }^{32}$ And yet, why is power intolerable? Isn't intolerability a normative feature of the existing predicament? As I shall show below, Foucault's characterization of power relations as "intolerable" straightforwardly points to the normative dimension of his work. Beforehand, however, it is necessary to illustrate the largely implicit model of critical reflection underlying Foucault's philosophical project.

\section{AGAINST THE MODERN REGIME OF TRUTH: CRITIQUE AS EMANCIPATORY PRACTICE}

To this end, allow me to briefly return to Habermas' reading of Foucault. As Habermas elaborates his critique, one can easily note that the latter is formulated on the basis of a skewed playing field. Tacitly relying on an exclusive description of critique as a measuring activity, Habermas condemns Foucault's genealogy for failing to meet the requirement of providing a rational justification of his claims grounded in universal and objective arguments. What Habermas' polemic overlooks, though, is that Foucault's genealogy amounts to a different practice of critique which refuses the kind of foundation Habermas demands. Indeed, by submitting the imperatives of modern rationalization to the judgement of the regulative ideal of an uncontaminated form of communicative reason founded on the universal rules of rational argumentation, for Foucault Habermas gets caught in "the blackmail of being either for or against the Enlightenment". ${ }^{33}$ As a result, Habermas is led to denounce as irrationalist all those who dispute the allegedly universal and absolute force of its values. On the contrary, against this blackmail, Foucault believes that the essential task of critical thought is not to put reason on trial, but rather to investigate reason's historical effects and limits, as well as its intrinsic dangers. ${ }^{34}$

In this sense, Foucault undertakes an analysis of how "focal points of experience" - i.e., constructed realities like madness, crime, and sexuality - have emerged out of an intricate

${ }^{31}$ Michel Foucault, "Interview with Michel Foucault," in Power: Essential Works of Foucault, Volume 3, ed. James D. Faubion, trans. Robert Hurley et al. (2000), 283.

${ }^{32}$ Kelly, For Foucault, 149.

${ }^{33}$ Michel Foucault, "What is Enlightenment?," in Ethics, Subjectivity, and Truth: Essential Works of Foucault, Volume 1, ed. Paul Rabinow, trans. Robert Hurley et al. (1997), 314.

${ }^{34}$ See Michel Foucault, "Space, Knowledge, and Power," in Power: Essential Works of Foucault, Volume 3, ed. James D. Faubion, trans. Robert Hurley et al. (2000), 358. 
set of discursive and non-discursive practices guided by historically specific rationalities, whose articulation results from the intersection between systems of knowledge, governmental strategies of power, and modes of subjectivation. ${ }^{35}$ More precisely, following his later retrospective accounts of his philosophical itinerary, the goal of Foucault's archaeogenealogical inquiries is to disclose the historical processes of problematization organizing the "conditions of acceptability" 36 of the current system of practices. Such a task entails the clarification of the entanglements between knowledge [savoir] and power [pouvoir] at the basis of their historical appearance, as well the forms of subjectivity they enable. In the first place, therefore, one can describe Foucault's project as a history of problematizations geared to explain how the current regime of practices has developed from a complex series of historical transformations in "'the ensemble of rules according to which the true and the false are separated and specific effects of power are attached to the true'" . As their contingent responses, the forms of rationality these problematizations make possible are nothing other than different ways of articulating the relationship between men's government of themselves and others on the one hand and, on the other, the production of discourses that society "accepts and makes function as true". ${ }^{37}$ Yet, Foucault does not present his enterprise solely in terms of a history of problematizations. He further qualifies it as being meant to "dissipate what is familiar and accepted, to re-examine rules and institutions and on the basis of this reproblematization [...] to participate in the formation of a political will" ${ }^{38}$ Consequently, through the archaeo-genealogical contestation of the inevitability and naturalness of our dangerously ossified practices, Foucault seeks not only to unmask the historical problematizations at the basis of their emergence in order to open them up to radically alternative responses; Foucault also strives to rethink "from the root the way men problematize their behaviour" 39 , so as to challenge the limits within which these problematizations confine our experiences.

Now, for Foucault, the success of this critical practice depends upon its ability to emancipate its addressees from the "regime of truth" moulding the uncontested horizon of their experiences. By the notion of "regime of truth", Foucault refers to the relationship of coimplication between the governmental technologies of modern biopolitics and the discourses of truth proper to human sciences, which determines the subjecting production of modern individuals as being marked by a two-faced identity: their identity as empirical, biosocial objects and their identity as autonomous, authentic selves. Whereas in 1976 Foucault still thinks that critique implies "detaching the power of truth from the forms of

\footnotetext{
35 See Michel Foucault, The Government of Self and Others. Lectures at the Collège de France 1982-83, ed. Arnold I. Davidson, Frédéric Gros, François Ewald, and Alessandro Fontana, trans. Graham Burchell (2010), 2-3.

${ }^{36}$ Foucault, "What is Critique?", 62.

${ }^{37}$ Michel Foucault, "Truth and Power," in Power/Knowledge: Selected Interviews \& Other Writings 1972-77, ed. Colin Gordon, trans. Colin Gordon et al. (1980), 131-132.

${ }^{38}$ Michel Foucault, "The Concern for Truth," in Politics, Philosophy, and Culture. Interviews and Other Writings 1977-84, ed. Lawrence D. Kritzman, trans. Alan Sheridan et al. (1988), 256, emphasis added.

${ }^{39}$ Michel Foucault, “À propos de la généalogie de l'éthique: un aperçu du travail en cours," in Dits et Écrits II, 1976-88, ed. Daniel Defert, François Ewald, and Jacques Lagrange (2001), 1431, my translation.
} 
hegemony, social, economic and cultural, within which it operates at the present time" 40 , in The Birth of Biopolitics Foucault modifies his description of the role of critique. Taking the cue from his account of liberalism as an art of government whose practices are organized around a partage between the true and the false indexed to market economy, here Foucault reinterprets his previous work as a "genealogy of regimes of veridiction", i.e., as the historical analysis of the constitution of realities like madness, crime, and sexuality in light of the coordination of series of practices with a certain regime of truth. Foucault can thus maintain that the political role of critique lies in its capacity to determine "under what conditions and with what effects a veridiction is exercised". This means that the primary target is not so much the mechanisms of power responsible for the production of truth, as is still the case in 1976, but rather the very "rules of verification and falsification" that inform our practices. ${ }^{41}$

Still, how can critique deliver its addressees from the operations of truth that entrench the dominant forms of subjec(tiva)tion? Clearly enough, critique cannot be limited to an activity aimed at falsifying what is accepted as true, since that would leave untouched the system of rules for the division between the true and the false structuring our schemes of intelligibility. On Foucault's view, instead, the point of critique is to short-circuit the regime of truth and error "through which being is historically constituted as experience". ${ }^{42}$ To this end, Foucault engages in the construction of historical "fictions", i.e., counter-histories that call into question the ruling nexus of power-knowledge not "by playing a game [...] totally different from the [existing] game of truth, but by playing the same game differently". ${ }^{43}$ Neither true nor false with respect to the prevalent truth-regime, fictions enable Foucault to elaborate transfigurative interpretations of the historical reality, which serve two interrelated functions: on the one hand, they make visible the power-laden conditions at the root of our supposedly universal and necessary truths, thereby producing a change in people's "forms of sensibility and thresholds of tolerance" that detaches them from current dispositifs of power-knowledge. ${ }^{44}$ On the other, fictions also represent invitations for both the author and his addressees to intervene in the lines of rupture they

\footnotetext{
40 Foucault, "Truth and Power", 133.

${ }^{41}$ Michel Foucault, The Birth of Biopolitics. Lectures at the Collège de France (1978-79), ed. Arnold I. Davidson, Michel Senellart, François Ewald, and Alessandro Fontana, trans. Graham Burchell (2008), 35-36. Admittedly, a comprehensive discussion of Foucault's notion of regime of truth would require including here the analysis of the outline of a political history of truth Foucault sketches in his 1979-80 lectures at the Collège the France On the Government of the Living. For some insightful comments, see Daniele Lorenzini, Le force du vrai. De Foucault à Austin (2017). My decision to omit it is deliberate, being motivated by the limited space available. Moreover, whereas its reformulation in On the Government of the Living hinges on the dimension of subjectivity (see Michel Foucault, On the Government of the Living Lectures at the College de France (1979-80), ed. Arnold I. Davidson, Michel Senellart, François Ewald, and Alessandro Fontana, trans. Graham Burchell (2014), 49-50), Foucault's definition of the notion of regime of truth in The Birth of Biopolitics is focused on the element of truth, which makes it more congenial to the argument I intend to elaborate in this section.

${ }^{42}$ Michel Foucault, The Use of Pleasure. Volume 2 of The History of Sexuality, trans. Robert Hurley (1990), 6-7.

43 Foucault, "The Ethics of the Concern for Self as a Practice of Freedom", 295.

${ }^{44}$ Michel Foucault, "Questions of Method," in Power: Essential Works of Foucault, Volume 3, ed. James D. Faubion, trans. Robert Hurley et al. (New York: New Press, 2000), 234.
} 
unravel and experiment with alternative possibilities of relating to themselves and contemporary experience. ${ }^{45}$ Re-examining The Will to Knowledge in view of these methodological remarks, for example, Foucault's diagnosis of biopower fabricates a counter-history that disrupts our adherence to the sovereign-based, juridico-repressive conception of power marking the discourse of humanism. By pointing out the connection of our will to sexual truth with a global and productive strategy of power aimed at governing individuals and populations alike, Foucault shows that the stake of a politics of resistance is not the desire to liberate our authentic sexual identity (itself allied with the mechanisms of normalization), but rather the invention of a different political "economy of bodies and pleasures" 46 as a corrective against the sex-desire couple at the basis of the truth-regime of the modern dispositif of sexuality. In sum, Foucault's genealogy describes a problematizing mode of critical inquiry designed to free us from what Owen calls our regime of "aspectival captivity" 47 , i.e., from the exclusive, self-imposed order of truths shaping the seemingly unsurpassable limits of our thought, practices, and forms of subjectivity.

If that is true, however, from a Habermasian perspective one could object that without a neat separation between power and validity any talk about freedom is meaningless. As other prominent critics like Taylor, Rorty, and Walzer argue, in fact, freedom can be conceived only in two ways: either as liberation from power altogether, or as voluntary subjection to a form of power whose legitimate authority has been agreed upon without any power constraint intervening into the process. ${ }^{48}$ In this respect, since Foucault qualifies the emancipatory force of liberation by showing its tactical usage within wider power strategies, any reference to freedom in his work should be read at best as a revision of his earlier anti-humanist stance or, at worst, as the expression of an incoherent attitude verging on a form of anarchism and "aesthetic decisionism". ${ }^{9}$ Yet, these readings neglect one of Foucault's major innovations, which is to say his rejection of the idea that freedom and power stand in a relation of mutual exclusion. As his late reformulation of power as

\footnotetext{
45 See Foucault, "Interview with Foucault", 243.

${ }^{46}$ Michel Foucault, The History of Sexuality, Volume 1: An Introduction (The Will to Knowledge), trans. Robert Hurley (1978), 159.

47 See David Owen, "Criticism and Captivity: On Genealogy and Critical Theory," European Journal of Philosophy 10:2 (2002).

48 See Charles Taylor, "Foucault on Freedom and Truth," in Foucault: A Critical Reader, ed. David C. Hoy (1986); Richard Rorty, "Moral Identity and Private Autonomy," in Michel Foucault Philosopher, ed. François Ewald, trans. Timothy J. Armstrong (1992); Michael Walzer, “The Politics of Michel Foucault," in Foucault: A Critical Reader, ed. David C. Hoy, (1986).

${ }^{49}$ Walzer "The Politics of Michel Foucault," 53. Admittedly, Rorty proposes a subtler version of this criticism, whereby Foucault would be guilty of conflating two roles: on the one hand, as a public intellectual, he was a "humanitarian bourgeois liberal". On the other, as a private citizen, he was also "a knight of autonomy" strenuously engaged in practices of self-transformation. For Rorty, this conflation has led him to endorse a quasi-anarchic stance marked by the dangerous transposition of his quest for autonomy at the social level. Suggesting a depoliticized reading of his notion of freedom, then, Rorty concludes that Foucault should have kept the two roles separate by limiting autonomy within the realm of negative liberty ensured by the liberal state, whose goal is "not to invent or create anything, but simply to make it as easy as possible for people to achieve their widely different private ends without hurting each other" (Rorty, "Moral Identity and Private Autonomy", 330-331).
} 
government makes clear, in fact, Foucault thinks that as a mode of action structuring "the possible field of action of others", power finds the condition of its exercise in human subjects' freedom to conduct themselves in several ways. The latter include accepting to be obedient and governable subjects, but also giving form to "the intransigence of freedom" by withdrawing their consent to submit to the predominant mechanisms of power. ${ }^{50} \mathrm{Ac}-$ cordingly, pointing to the existence of alternative possibilities of freedom immanent in the existing regime of power, Foucault implicitly criticizes Habermas for failing to note that

the problem [...] is not to try to dissolve them [i.e., power relations] in the utopia of completely transparent communication but to acquire the rules of law, the management techniques, and also the ethics [...] that will allow us to play these games of power with as little domination as possible..$^{51}$

The importance of this passage for the economy of my argument can be hardly overestimated: indeed, as I shall show in the next section, here Foucault indirectly identifies in the struggle for freedom as self-transformation the evaluative perspective marking his critical philosophy, whose stand point provides the normative reasons that Fraser thinks Foucault fails to supply in order to account for his rejection of humanism.

\section{ENLIGHTENMENT, SELF-TRANSFORMATIVE FREEDOM AND EXEMPLARITY}

As we have just seen, Foucault's later reformulation of power as government is premised upon a conception of human subjects as free agents who have the capacity to shape the thought and actions of others as well as their own. ${ }^{52}$ This new paradigm of power as government persuades Foucault of the necessity to distinguish between three levels in the analytics of power: power, domination, and governmental technologies. ${ }^{53}$ Though the point is well-known, allow me to recall it for the sake of clarity: (1) power describes a mobile and reversible set of strategic relations between liberties co-extensive with the entire social body, in which one tries to orchestrate the space of possible action of others. (2) These relations are opposed to states of domination, in which a person or a group has been able to crystallize strategic relations into hardly reversible, fixed, and asymmetrical structures of power, thereby reducing the exercise of and opportunity for freedom to its smallest margin. (3) Finally, one must also distinguish the intermediate level of governmental technologies, namely of all those systematized forms of power resulting from the dangerous tendency of strategic relations to coagulate into stable configurations, which

\footnotetext{
${ }^{50}$ Michel Foucault, “The Subject and Power", 341-342.

${ }^{51}$ Foucault, "The Ethics of the Concern for Self as a Practice of Freedom", 298.

52 Foucault, "The Subject and Power", 340. As Patton has compellingly showed, Foucault's late distinction between power as a relational structure (power over) and power as potere (power to) is already at work in his earlier genealogical work. Here, though, the terms Foucault employs are different: "power" stands for "power over", while "force" replaces "power to". See Paul Patton, "Taylor and Foucault on Power and Freedom," Political Studies 37 (1989).

${ }^{53}$ Foucault, “The Ethics of the Concern for Self as a Practice of Freedom”, 299.
} 
in turn might engender states of domination. Contrary to what is often assumed, however, for Foucault states of domination are an exceptional, extreme case in power relations. ${ }^{54}$ That is the reason why Foucault prefers to concentrate his attention on governmental technologies as those systems of power within which individuals' submission to the obligations associated with the dominant regime of truth produces a form of aspectival captivity undermining their capacity to recognize themselves as (un)free agents. As a result, critics are mistaken when they claim that Foucault does not give us normative resources to establish why power ought to be resisted: insofar as he is able to explain how we have become enthralled by the truths that adjust our processes of self-constitution to the identificatory ambitions of the current mechanisms of governmental power, Foucault shows that we are ethically and politically motivated to revolt against the power relations shoring up our regime of aspectival captivity:

The most important question [...] is not whether a culture without restraints is possible or even desirable but whether the system of constraints in which a society functions leaves individuals the liberty to transform the system. [...] a system of constraint becomes truly intolerable when the individuals who are affected by it don't have the means of modifying it..$^{55}$

In this sense, by showing the historical contingency of our sedimented practices and the possibility that they could be something different, Foucault seeks to provide us with alternative modes of understanding our experience. These enable us to acknowledge the normative salience not only of questioning the historical problematizations at the root of the practices constitutive of our present, but also of engaging in the hazardous work of experimentally tailoring self-transformative answers to these very same problematizations. Put briefly, as a partisan practice of inquiry, the goal of Foucault's archaeo-genealogical critique is to "give new impetus [...] to the undefined work of freedom" 56 , facilitating our involvement in games of power with a minimum of domination. Indeed, as Foucault claims,

it is here that we will find the real possibility of constructing a history of what we have done and, at the same time, a diagnosis of what we are. [...] this theoretical analysis would have a political dimension [...] that relates to what we are willing to accept in our world - to accept, to refuse, and to change, both in ourselves and in our circumstances. In sum, it is a question of searching for a new kind of critical philosophy. Not a critical philosophy that seeks to determine the conditions and the limits of our possible

\footnotetext{
${ }^{54}$ As Foucault himself states, "power relations are extremely widespread in human relationships" but one "sometimes encounters [...] situations or states of domination" (Ibid., 283, emphasis added).

${ }^{55}$ Foucault adds: "This can happen when such a system becomes intangible as a result of its being considered a moral or religious imperative, or a necessary consequence of medical science", Michel Foucault, "Sexual Choice, Sexual Act," in Ethics, Subjectivity, and Truth: Essential Works of Foucault, Volume 1, ed. Paul Rabinow, trans. Robert Hurley et al. (1997), 147-148, emphasis added.

${ }^{56}$ Foucault, “What is Enlightenment?," 316.
} 
knowledge of the object, but a critical philosophy that seeks the conditions and the indefinite possibilities of transforming the subject, of transforming ourselves. ${ }^{57}$

At this stage, we are in a good position to comprehend why, from a Foucauldian perspective, the fully panopticized society Fraser depicts should be contested. Although it describes a state of structural autonomy, in Foucault's view the governmental mechanisms of disciplinary power marking this hypothetical society would produce a barely visible and alterable state of domination ${ }^{58}$, which should be rejected because it would entrench the condition of aspectival captivity associated with the modern regime of truth, thereby blocking the more dynamic realization of freedom as self-transformation. Indeed, a wholly panopticized society would dangerously present the rationality of humanism as a "universal model [valid] for any kind of freedom". ${ }^{59} \mathrm{~A}$ wholly panopticized society would thus restrict freedom within the frontiers that define the horizon of possibilities for thought and action associated with the commitment to our identification as autonomous and authentic selves as well as the correlative preservation of the democratic order through the ever-refined mechanisms of biopower. As I have clarified above, instead, the point of Foucault's inquiries is precisely to disclose the historical contingency of the limits our humanist truths impose upon our experience as free subjects. More precisely, Foucault encourages us to fashion self-transformative responses to the historical problematics we face, which are meant to broaden our sense of the possible and create a "new economy of power". ${ }^{60}$ In this respect, as the normative basis of his account of modern dangers, Foucault's conception of freedom as self-transformation should be clearly demarcated from normative appeals to Kantian autonomy as the power to rationally determine one's choice without interference in the context of a normative framework of pre-established options. ${ }^{61}$ If freedom were only so conceived, in fact, one would run the risk of lapsing back into the conception of freedom connected to the juridico-repressive model of power, while missing how modern biopolitics operates by governmentally pre-structuring "possible or actual future or present actions" 62 within a given field of possibilities. Rather, far from being

\footnotetext{
${ }^{57}$ Michel Foucault, "Subjectivity and Truth," in The Politics of Truth, ed. S. Lotringer, trans. L. Hochroth and C. Porter (2007), 152-153.

58 Admittedly, the governmental technologies of Fraser's hypothetical society would be so perfected to obviate some of the characteristics Foucault ascribes to states of domination according to his late definition reported at the beginning of this section. As Fraser argues, in fact, hierarchical and asymmetrical power relations would be dispensable, because "disciplinary norms [...] would not be experienced as coming from without" (Fraser, "Michel Foucault: A 'Young Conservative'?", 203). To reformulate my claim here, however, the fully panopticized society Fraser depicts would still present what Foucault considers to be the truly distinctive feature of states of domination, namely the rigid and scarcely changeable nature of their imperceptible system of power.

${ }^{59}$ Foucault, "Truth, Power, Self: An Interview with Michel Foucault," in Technologies of the Self: A Seminar with Michel Foucault, ed. Luther H. Martin, Huck Gutman, and Patrick H. Hutton (1988), 15.

${ }^{60}$ Foucault, "The Subject and Power", 328.

${ }^{61}$ Among others, for a recent interpretation of Foucault as embracing "the Kantian ideal of autonomy as the source of value", see Tuomo Tiisala, “Overcoming 'the Present Limits of the Necessary': Foucault's Conception of a Critique," Southern Journal of Philosophy 55, no. S1, Spindel Supplement (2017), 15.

62 Foucault, "The Subject and Power", 340.
} 
reducible to the space of negative liberty promoted by the liberal rationality of government, my claim is that Foucault's concept of freedom should be better understood as a practice of self-empowerment involving at one and the same time two different but tightly interrelated moves: on the one hand, a subtractive act of "desubjection" [désassujettissement $]^{63}$ (Foucault 2007, 47) from the governmental mechanisms of power crafting individuals' conduct according to the dominant regime of truth. On the other, an ethico-political practice of creative stylization marking any concrete engagement in new processes of subjectivation aimed at reshaping the problematizations that condition who we are. As an illustration, discussing the gay movement, Foucault asserts:

It is [...] necessary to struggle to establish homosexual lifestyles, existential choices in which sexual relations with people of the same sex will be important. [...] It's not [...] a matter of integrating this strange little practice of making love with someone of the same sex into pre-existing cultures; it's a matter of constructing [créer] cultural forms. ${ }^{64}$

Since Aristotle, the traditional conception of possibility thinks of the latter as dependent on actuality. On the contrary, for Foucault, the issue is to overturn this hierarchical relation by enabling individuals to devise still unexplored existential possibilities that are reducible neither to mere logical possibilities, nor to the pre-established space of what is actually possible according to the governmental and impoverished logic of our modern social world. Hence, Foucault's aim is to foster individuals' capacity to trigger specific changes through the practical invention of "modalities of relationship, modes of existence, types of values, forms of exchange between individuals which would be really new" ${ }^{\prime 6}$ To state it otherwise, what Foucault pleads for is not so much the acknowledgement of one's mode of living within the existing social order, but rather a rearrangement of the framework of intelligibility employed to make sense of the actuality and what is possible through the introduction of "a whole series of other values and choices for which there are not yet real possibilities". ${ }^{66}$ Accordingly, Foucault's model of critique encourages us to recognize that, as one of the historically specific forms human freedom can take, the humanist value of autonomy has lost much of its normative pull and needs to be replaced with an expanded and renewed paradigm of freedom as capacity for self-transformation, i.e., to become other than we are. The latter is driven by what Foucault describes as the challenge of discovering possible ways of disconnecting "the growth of capabilities [ $\mathrm{ca}$ pacités] [...] from the intensification of power relations" ${ }^{67}$ On my view, however, it is crucial not to disjoin this open-ended capacity for self-transformation from its practical

\footnotetext{
${ }^{63}$ Foucault, "What is Critique?", 47.

${ }^{64}$ Foucault, "The Social Triumph of the Sexual Will", 157.

65 Ibid., 159-160, translation amended. In this respect, although she misses Foucault's dual characterization of freedom, Han correctly speaks of Foucault's notion of freedom as "ontologically disclosive power", see Béatrice Han[-Pile], "Nietzsche and Foucault on Style: The Limits of the Aesthetic Paradigm," in Nietzsche, Postmodernismus und was nach ihnen kommt, ed. Endre Kiss and Uschi Nussbaumer-Benz (2000), 12. References are to manuscript.

${ }^{66}$ Foucault, "The Social Triumph of the Sexual Will", 157.

${ }^{67}$ Foucault, "What is Enlightenment?", 317.
} 
actualization. In this respect, Allen's characterization of Foucault's notion of freedom exclusively as "capacities for critical reflection and self-transformation" 68 runs the risk of conceptualizing freedom as if it could be assured by specific institutional arrangements. Conversely, Foucault insists that freedom "must be exercised" and there is no other guarantee of freedom than freedom itself. ${ }^{69}$ As a result, for Foucault, freedom should be understood not as submission to the moral law or as a regulative idea like in Kant, but rather as the exercise of a historically situated disclosive force that demarcates the limits beyond which the subjection to power becomes intolerable. This means that freedom can exist only in actu, in the voluntary acts of creative desubjection of particular agents. It is through constant innovation alone that we can contrast the danger for freedom of being (re)captured by new dispositifs of seizure, in the hope that history's reservoir of possibilities will enable us to produce liberating cultural forms out of the materials of our present. That is the reason why, for Foucault, archaeology and genealogy remain needed: by reconstructing the multiple set of historical conditions of possibility at the basis of the modern regime of truth, their problematizations induce a discomforting change of perspective that estranges us from our practices and their guiding rationalities "so as to reveal [them] at a distance". ${ }^{70}$ Such an operation not only facilitates the emergence of the breaking points where our forms of intelligibility begin to flake apart, but also brings to light historical materials that might be used to foster radical transformations in the present. Indeed, as Foucault himself claims in a late interview,

among the cultural inventions of mankind there is a treasury of devices, techniques, ideas, procedures, and so on, that cannot exactly be reactivated but at least constitute [...] a certain point of view which can be very useful as a tool for analysing what's going on now - and to change it. ${ }^{71}$

According to such a perspective, pace its consensus-oriented detractors (and in particular Rorty), Foucault's immanent practice of critical self-reflection does not appeal to a preliminary assumption about the identity of the "we" involved in the normative question "what are we to do?", whose coordinates would define the conditions of legitimacy for criticism. Rather, Foucault rejects any supposedly authentic truth about who we are in order to clear

\footnotetext{
68 Amy Allen, The Politics of Our Selves. Power, Autonomy, and Gender in Contemporary Critical Theory (2008), 2. Contrastively, for an outright rejection of this reading in terms of "capacities", see Johanna Oksala, Foucault on Freedom (2005), 188.

${ }^{69}$ Foucault, "Space, Knowledge, and Power", 354-355. In addition, Koopman highlights that theorizing freedom only in terms of "capacity" invites to think of it as being possessed by a transcendental subject of the kind Foucault strove to discard (see Koopman, Genealogy as Critique, 208). For a Deleuzian reading of Foucault's conception of freedom erroneously based on the non-enunciable and aprioristic metaphysical category of "the outside", which Foucault already criticizes in the Archaeology of Knowledge, see Sergei Prozorov, Foucault, Freedom and Sovereignty (2007).

${ }^{70}$ Michel Foucault, "Nietzsche, Genealogy, History," in Aesthetics, Method, and Epistemology: Essential Works of Foucault, Volume 2, ed. James D. Faubion, trans. R. Hurley et al. (1998), 382, translation amended.

${ }^{71}$ Foucault, “On the Genealogy of Ethics: An Overview of Work in Progress”, 261.
} 
up the space for the creation of a "we" in the future. ${ }^{72}$ The normative success of Foucault's philosophical enterprise, therefore, depends upon its fallible and modest contribution to the formation of a "community of action" engaged in the "historico-practical test" [mise à l'épreuve] of the alternative possibilities for emancipation disclosed by his archaeo-genealogical investigations. ${ }^{73}$

This means that Foucault's critical practice does not consist in legislating what justice is on behalf of the oppressed, but rather in promoting their struggle through the contestation of the historical limits constraining the forms of freedom within the social order generated by the synergic confluence of the modern techniques of biopolitical government with the conceptual apparatus of humanism. ${ }^{74}$ However, contrary to what Oksala suggests at times ${ }^{75}$, his repudiation of a prescriptive stance does not help us reply to the fundamental question of how Foucault can vindicate his normative claims. Such a denial, in fact, rests upon the very respect for individual freedom. Granted that for Foucault the current systems of power-knowledge are supple enough to include "resources that enable their own critique and transformation"76, then, one might still object that his critique remains unwarranted, insofar as Foucault is not able to provide an account of the normative value of freedom as self-transformation underpinning his enterprise. As is further confirmed by his refusal of prescriptivity, we have already seen that Foucault rejects justificatory accounts of normativity based upon independent grounds communicated in the form of discursive arguments. These accounts presuppose some dangerous kind of universalistic foundations that leads to the absolutisation of an exclusive perspective on reality and the correlative subordination of individuals to the ideal society it supports. What options other than discursive grounding are we left with to redeem Foucault's position from the charge of dogmatism? Recently, Han has proposed the following strategy. According to her argument, the source of normativity does not lie in any type of discursive justification, because "this would get the ethical phenomenology wrong". Rather, it rests upon the "ethical sensitivity we acquire from familiarity with our culture and practices", which are part of the Enlightenment inheritance. For Han, therefore, "such sensitivity is the ground of our ethical life and pre-empts the need for justification". ${ }^{77}$ Although Han is correct when she criticizes the appropriateness of his detractors' demand that Foucault should provide us with a justificatory account of his critical remarks, I think her focus on the ethical aspect of Foucault's thought overlooks that the latter is inextricably entwined with a political dimension whose normative requirements seem to remain unmet in her answer. As Oksala puts the point, one's ethics might be based on "unthematized values and experiences of liberations". The need for a normative account, however, "becomes

\footnotetext{
72 Foucault, "Polemics, Politics, and Problematizations," in Ethics, Subjectivity, and Truth: Essential Works of Foucault, Volume 1, ed. Paul Rabinow, trans. Robert Hurley et al. (1997), 114-115.

${ }^{73}$ Foucault, "What is Enlightenment?", 316.

${ }^{74}$ See Foucault, "Interview with Michel Foucault", 288.

75 See Oksala, Foucault on Freedom, 180.

${ }^{76}$ Allen, The Politics of Our Selves, 43.

77 Béatrice Han[-Pile], "Foucault, Normativity and Critique as a Practice of the Self," Continental Philosophy Review 49:1 (2016), 96.
} 
more pressing in connection with [emancipatory] politics", since emancipatory politics calls for normative ideals that "can be communicated and shared as a common political [...] goal". ${ }^{78}$ Consequently, below I shall propose a different reading which relies on Foucault's late essay "What is Enlightenment?". My claim is that here Foucault offers a context-dependent, explanatory account of the normative force of his critical ontology of the present. To begin with, Foucault maintains that the Enlightenment represents a privileged field of inquiry comprising economic, social, political, cultural, and technological processes that still determine, to a large extent, our forms of thought, patterns of behaviour, and normative commitments. "As an enterprise for linking the progress of truth to the history of liberty", Enlightenment also introduces a philosophical question that remains the focus of our concerns. Most importantly, however, Foucault adds that the Enlightenment inaugurates a type of philosophical interrogation preoccupied with the question of what in the present has meaning for philosophical reflection, a modern ethos that can be defined as "a permanent critique of our historical era". The shift that Foucault operates here is crucial. As he argues, "the thread that may connect us with the Enlightenment is not faithfulness to doctrinal elements". ${ }^{79}$ An unquestioned adherence to the substantive themes and commitments of the Enlightenment as they have been handed down to us, in fact, would entrench our condition of aspectival captivity to the truth-regime of humanism with which Enlightenment itself has been historically identified. Rather, what may connect us with the Enlightenment is an ethico-political task which can be described in terms of the reactivation of a "limit-attitude". By the latter Foucault means "an ethos, a philosophical life in which the critique of what we are is at one and the same time the historical analysis of the limits imposed on us and an experiment with the possibility of going beyond them [de leur franchissement possible]"..$^{80}$ To state it otherwise, far from being a theory or a doctrine, Foucault's project of a critical ontology of ourselves is a practice of reflection on limits as "work carried out by ourselves upon ourselves as free beings". ${ }^{81}$ Through concrete and specific inquiries, such a practice reveals the contingent processes at the basis of the identities we have come to endorse and, in so doing, creates a space to imagine transformative modalities of relationship to ourselves and others capable of fostering altered and circumscribed changes that might "pull us free from our modern age" .82 As a result, replacing transcendental criticism with an archaeo-genealogical method of investigation, the normative quality of Foucault's thought does not stem from a mere adoption of the historical values of the Enlightenment, including a substantive commitment to autonomy. ${ }^{83}$ Rather, it derives from the effort to relaunch the emancipatory thrust

\footnotetext{
${ }^{78}$ Oksala, Foucault on Freedom, 175.

${ }^{79}$ Foucault, “What is Enlightenment?", 313-314.

80 Ibid., 319.

81 Ibid., 316.

82 Michel Foucault, "On the Ways of Writing History," in Aesthetics, Method, and Epistemology: Essential Works of Foucault, Volume 2, ed. James D. Faubion, trans. R. Hurley et al. (1998), 293, translation amended.

${ }^{83}$ See Oksala, Foucault on Freedom, 187.
} 
of the Enlightenment project by way of a reconceptualization of freedom as an ethicopolitical attitude oriented to self-transformation.

But what is the standard to judge the validity of this normative stance? Whereas Foucault does not look for further grounds, I think the answer to this question lies in the exemplary nature of his practice of critique. Consider the following passage:

At every moment, $[\ldots]$ one must confront what one is thinking and saying with what one is doing, with what one is. [...] The key to the personal political attitude of a philosopher is not to be sought in his ideas, as if it could be deduced from them, but rather in his philosophy-as-life, in his philosophical life, his ethos. ${ }^{84}$

The passage clearly shows the attention Foucault devotes to a stylisation of an exemplary coincidence between logos and bios, whereby his own life becomes the surface of exploratory processes of experimentation. Here, I am referring not just to the well-known description of each of his studies as "a fragment of autobiography" 85 , but also to Foucault's militant engagement in various struggles against specific relations of power. ${ }^{86}$ Testing his ethos, all these activities oriented to conjugate logos and bios enable Foucault to present himself as an exemplum, whose normative authority derives from the recognition obtained from his addressees. But such exemplarity is not restricted to Foucault's figure as public citizen. Rather, it comes to be reflected in the "neutralization" 87 of the normative effects implicit in the humanist vocabulary of legitimacy, truthfulness, and authenticity Foucault enacts through his archaeo-genealogical reformulation of the concepts of power, knowledge, and the subject. ${ }^{88}$ This reformulation expresses the appeal to the value of freedom underpinning his model of critique as a problematizing activity directed to emancipate his addressees from the current regime of truth, a theoretical operation that exemplifies the politics of resistance Foucault advocates against the "double bind" of modern biopower. ${ }^{89}$ In brief, the confidence one can have in the validity of his normative position hangs upon Foucault's ability to give embodied form to the Enlightenment ethos in his

\footnotetext{
${ }^{84}$ Foucault, "Politics and Ethics: An Interview", 374, translation amended.

${ }^{85}$ Michel Foucault, “So Is It Important to Think?," in Power: Essential Works of Foucault, Volume 3, ed. James D. Faubion, trans. Robert Hurley et al. (2000), 458.

${ }^{86}$ For a detailed reconstruction of Foucault's political activism, see Marcelo Hoffman, Foucault and Power: The Influence of Political Engagement on Theories of Power (2015). One should not forget to mention the personal "test" to which Foucault submitted his conception of identity through the indulgence in unconventional sexual practices. See James E. Miller, The Passion of Michel Foucault (1993).

${ }^{87}$ Foucault, "What is Critique?", 60.

${ }^{88}$ Although he underestimates the disclosive, experimental moment of Foucault's notion of critique, for a detailed examination of the imperatives of nihilism, nominalism, and historicism underpinning Foucault's archaeo-genealogical method, see Frieder Vogelmann, "Critique as a Practice of Prefigurative Emancipation," Distinktion: Journal of Social Theory 18:2 (2017).

${ }^{89}$ Foucault, "The Subject and Power", 336. Elsewhere, I have shown how in the last years of his life Foucault progressively comes to think of his own critical engagement as modelled on the exemplarity of the Socratic practice of parrhesiastic truth-telling. See Giovanni Maria Mascaretti, "Michel Foucault on Problematization, Parrhesia and Critique," Materiali Foucaultiani 3, no. 5-6, (2014). On the idea of Foucault's genealogy as exemplifying a creative politics of resistance, see also David Owen, Maturity and Modernity. Nietzsche, Weber, Foucault and the Ambivalence of Reason (1994), 210-212.
} 
style of existence as well as theoretical production, whereby the exemplarity of his critique ensures that the latter is as redeemed as it could be.

\section{CONCLUDING REMARKS}

Despite the soundness of this strategy, however, I believe Foucault's normative approach is not deprived of serious incongruences and shortfalls which mark open-ended spaces of reflection for us to explore. I shall point only to three of them. Firstly, one cannot gloss over the clash between the interpretative-evaluative perspective described above and some more circumstantial observations. In a 1979 statement on the Iran Revolution, for instance, Foucault writes that his "theoretical ethic is [...] 'antistrategic': to be respectful when a singularity revolts, intransigent as soon as power violates the universal" 190 . To my eyes, passages like this one are not only incoherent with respect to Foucault's sceptical rejection of universals, but they also leave pending a whole series of normative questions: what constitutes the universal Foucault makes reference to? And why should we assume it as a reason for revolting against power?

Secondly, as we have seen, for Foucault the dangerousness of power relations consists in their tendency to congeal into governmental technologies, which in turn might engender states of domination. Notwithstanding the lack of a compelling analysis of what drives the propensity for domination in a historically specific context, however, it seems to me that Foucault's appeal to freedom as self-transformation constitutes an insufficient normative resource to adjudicate between the various creative responses one can forward in order to contrast this tendency. Foucault could reply that it is not up to the critic to tell what is to be done. Nevertheless, he also admits that the initiatives one can undertake are "not equally dangerous". ${ }^{91}$ But that is precisely where Foucault's reasoning breaks off: indeed, besides his normative appeal to freedom, he never clarifies what renders one course of action more appropriate and desirable than another, thereby failing to consider the role played by argumentative practices in the elaborations of one's critical position.

Finally, the inadequate attention Foucault pays to the level of argumentation has implications also for his conception of political struggle. Far from being limited to a confrontation between two opposing poles, in fact, political struggle involves complex dynamics that affect also those who are not directly concerned by the power relations under examination. The effectiveness of an emancipatory struggle, in fact, depends upon its capacity to gain a foothold in public opinion through the argumentative elucidation of the values and instances that propel it. In his later studies, Foucault was progressively led to acknowledge the relevance of this dimension, but nonetheless - due to his premature

\footnotetext{
${ }^{90}$ Michel Foucault, “Useless to Revolt?," in Power: Essential Works of Foucault, Volume 3, ed. James D. Faubion, trans. Robert Hurley et al. (2000), 453.

${ }^{91}$ Foucault, "Ethics and Politics". To the problematization of the prison function, for example, Foucault holds that "one can reply by means of revolt, reform, or the destruction of prisons". Michel Foucault, "Luttes autour des prisons," in Dits et Écrits II, 1976-88, ed. Daniel Defert, François Ewald, and Jacques Lagrange (2001), 813 , my translation.
} 
death - his remarks are left largely underdeveloped..$^{92}$ In any case, that should be read as a symptom not of Foucault's wish to return to the figure of the universal intellectual, but rather of a change of attitude promoted by the awareness of the need for a public dialogue aimed at charting the best options for altering the current state of affairs:

I am a little bit irritated by an attitude, which has been mine for a long time and which now I do not subscribe to anymore, according to which one says: our problem is to denounce and to criticize; let them sort things out with their legislation and their reforms. That does not seem to me a right attitude. ${ }^{93}$

In conclusion, the opening of this article presented Fraser's formulation of the problem of normativity that seems to affect Foucault's method. Without a new paradigm of freedom disentangled from the normative grammar of humanism, Fraser maintains, Foucault is unable to answer why a fully panopticized, autonomous society should be resisted. As a response to her allegation, I argued for a normative reading of Foucault's practice of critique as being marked by a distinctive appeal to the ideal of freedom as self-transformation. This enabled me to show that for Foucault the kind of society Fraser portrays ought to be opposed because it would constrain our experience as free agents within the forms of subjectivity imposed by our aspectival captivity to the prevailing regime of truth, which derives from the circular enmeshing of humanism with modern biopolitics. Whereas Foucault rejects the demand to discursively justify the right of criticism on universalistic and foundationalistic grounds, I clarified that Foucault's late alignment of his thought to the Enlightenment provides us with a historically contextual, explanatory account of the normative force of his orientation to freedom. According to this account, the ultimate motivation of Foucault's critical attitude is represented by a project of problematization of the existing normative commitments, which aims to transform them so as to give new impetus to the emancipatory claims of Enlightenment modernity. Finally, I showed that the yardstick to evaluate the cogency of this normative enterprise is represented by the congruence Foucault establishes between what he says and what he does, namely by the exemplary embodiment of the critical ethos of the Enlightenment both in his experimental style of existence and in the intellectual production of new diagnostic concepts capable of unsettling the epistemological framework of humanism. Hence, I offered a way to put to rest the long-standing complaint that Foucault does not tell us why power ought to be resisted. Still, what we have now seen in closing is that Foucault's normative strategy remains wanting in important respects, since it does not elaborate on the conceptual tools necessary to develop the reconstructive possibilities opened up by his critical inquiries.

\footnotetext{
92 Due to space constraints, I have to leave the analysis of this aspect of Foucault's thought to another occasion. For some preliminary, inspiring remarks, see Vincenzo Sorrentino, Il pensiero politico di Foucault (2008), 246-275.

93 Michel Foucault, “Enfermement, Psychiatrie, Prison," in Dits et Écrits II, 1976-88, ed. Daniel Defert, François Ewald, and Jacques Lagrange (2001), 360, my translation.
} 


\section{References}

Allen, Amy, The Politics of Our Selves. Power, Autonomy, and Gender in Contemporary Critical Theory. New York: Columbia University Press, 2008.

Bernstein, Richard J., "Foucault: Critique as Philosophical Ethos," in Critique and Power: Recasting the Foucault/Habermas Debate, ed. Michael Kelly, 211-241. Cambridge, MA: MIT Press, 1994.

Foucault, Michel, History of Sexuality, Volume 1: An Introduction (The Will to Knowledge). Translated by Robert Hurley. New York: Pantheon Books, 1978.

Foucault, Michel, Power/Knowledge: Selected Interviews \& Other Writings 1972-77. Ed. Colin Gordon, translated by Colin Gordon et al. New York: Pantheon Books, 1980.

Foucault, Michel, "Ethics and Politics". Unedited and unpublished full interview with Paul Rabinow, Richard Rorty, Martin Jay, Leo Löwenthal, and Charles Taylor held at the University of California at Berkeley in April 1983. For a complete transcription see Foucault, Michel, "Discussion with Michel Foucault," in IMEC/Fonds Michel Foucault, D 250(8). Excerpts of this interview were later published in Foucault, Michel. "Politics and Ethics: An Interview," in The Foucault Reader, ed. Paul Rabinow, 373-380. New York: Pantheon Books, 1984.

Foucault, Michel, The Foucault Reader. Ed. Paul Rabinow. New York: Pantheon Books, 1984.

Foucault, Michel, Politics, Philosophy, and Culture. Interviews and Other Writings 1977-84. Ed. by Lawrence D. Kritzman, translated by Alan Sheridan et al. London and New York: Routledge, 1988.

Foucault, Michel, "Truth, Power, Self: An Interview with Michel Foucault," in Technologies of the Self: A Seminar with Michel Foucault, ed. Luther H. Martin, Huck Gutman, and Patrick H. Hutton, 9-15. Amherst: University of Massachusetts Press, 1988.

Foucault, Michel, The Use of Pleasure. Volume 2 of The History of Sexuality. Translated by Robert Hurley. New York: Vintage Books, 1990.

Foucault, Michel, Foucault Live: Collected Interviews, 1966-84. Ed. Sylvère Lotringer. New York: Semiotext(e), 1996.

Foucault, Michel, Ethics, Subjectivity, and Truth: Essential Works of Foucault, Volume 1. Ed. Paul Rabinow, translated by Robert Hurley et al. New York: New Press, 1997.

Foucault, Michel, Aesthetics, Method, and Epistemology: Essential Works of Foucault, Volume 2. Ed. James D. Faubion, translated by R. Hurley et al. New York: New Press, 1998.

Foucault, Michel, Power: Essential Works of Foucault, Volume 3. Ed. James D. Faubion, translated by Robert Hurley et al. (New York: New Press, 2000).

Foucault, Michel, Dits et Écrits II, 1976-88. Ed. Daniel Defert, François Ewald, and Jacques Lagrange. Paris: Gallimard, 2001.

Foucault, Michel, The Politics of Truth. Ed. S. Lotringer, translated by L. Hochroth and C. Porter. Los Angeles: Semiotext(e), 2007.

Foucault, Michel, The Birth of Biopolitics. Lectures at the Collège de France (1978-79). Ed. Arnold I. Davidson, Michel Senellart, François Ewald, and Alessandro Fontana, translated by Graham Burchell. New York: Palgrave MacMillan, 2008. 
Foucault, Michel, The Government of Self and Others. Lectures at the Collège de France 1982-83. Ed. Arnold I. Davidson, Frédéric Gros, François Ewald, and Alessandro Fontana, translated by Graham Burchell. New York: Palgrave MacMillan, 2010.

Foucault, Michel, On the Government of the Living Lectures at the Collège de France (1979-80), Ed. Arnold I. Davidson, Michel Senellart, François Ewald, and Alessandro Fontana, translated Graham Burchell. New York: Palgrave MacMillan, 2014.

Foucault, Michel, "The Analytic Philosophy of Politics," translated Giovanni Maria Mascaretti, Foucault Studies, no. 24 (June 2018), 188-200. DOI: https://doi.org/10.22439/fs.v0i24.5532

Fraser, Nancy, "Michel Foucault: A 'Young Conservative'?" in Critique and Power: Recasting the Foucault/Habermas Debate, ed. Michael Kelly, 185-210. Cambridge, MA: MIT Press, 1994.

Fraser, Nancy, "Foucault on Modern Power: Empirical Insights and Normative Confusions" in Unruly Practices: Power, Discourse and Gender in Contemporary Social Theory, 17-34. Minneapolis: University of Minnesota Press, 1989.

Fraser, Nancy, "Foucault's Body Language: A Posthumanist Political Rhetoric," in Unruly Practices: Power, Discourse and Gender in Contemporary Social Theory, 55-66. Minneapolis: University of Minnesota Press, 1989.

Habermas, Jürgen, The Philosophical Discourse of Modernity. Translated by Frederick Lawrence. Cambridge, MA: MIT Press, 1987.

Han[-Pile], Béatrice, “Nietzsche and Foucault on Style: The Limits of the Aesthetic Paradigm," in Nietzsche, Postmodernismus und was nach ihnen kommt, edited by Endre Kiss and Uschi Nussbaumer-Benz. Cuxhaven: Junghans, 2000 (references are to manuscript).

Han[-Pile], Béatrice, "Foucault, Normativity and Critique as a Practice of the Self," in Continental Philosophy Review 49:1 (2016), 85-101. DOI: https://doi.org/10.1007/s11007-015-9360$\underline{2}$

Hoffman, Marcelo, Foucault and Power: The Influence of Political Engagement on Theories of Power. London: Bloomsbury Publishing, 2015.

Kelly, Mark G. E., For Foucault: Against Normative Political Theory. New York: State University of New York Press, 2018.

Kelly, Michael, "Introduction," in Critique and Power: Recasting the Foucault/Habermas Debate, ed. Michael Kelly, 1-13. Cambridge, MA: MIT Press, 1994.

Koopman, Colin, Genealogy as Critique. Foucault and the Problems of Modernity. Bloomington: Indiana University Press, 2013.

Koopman, Colin, “Genealogy, Methodology, \& Normativity beyond Transcendentality: Replies to Amy Allen, Eduardo Mendieta, \& Kevin Olson," Foucault Studies 18 (October 2014), 261-273. DOI: http://dx.doi.org/10.22439/fs.v0i18.4665

Lorenzini, Daniele, Le force du vrai. De Foucault à Austin. Lormont: Éditions LE BORD De L'EAU, 2017.

Mascaretti, Giovanni Maria, "Michel Foucault on Problematization, Parrhesia and Critique," Materiali Foucaultiani 3, no. 5-6, (2014), 135-154. URL: http://www.materialifoucaultiani.org/images/09_mascaretti.pdf 
Mayes, Christopher R. Mayes, “Revisiting Foucault's 'Normative Confusions': Surveying the Debate Since the Collège de France Lectures," Philosophy Compass 10:12 (2015), 841-855. DOI: https://doi.org/10.1111/phc3.12274

Miller, James E., The Passion of Michel Foucault. London: Simon \& Schuster,1993.

Oksala, Johanna, Foucault on Freedom. Cambridge: Cambridge University Press, 2005.

Owen, David, Maturity and Modernity. Nietzsche, Weber, Foucault and the Ambivalence of Reason. London and New York: Routledge, 1994.

Owen, David, "Criticism and Captivity: On Genealogy and Critical Theory," European Journal of Philosophy 10, no. 2 (2002), 216-230. DOI: https://doi.org/10.1111/1468-0378.00158

Patton, Paul, "Taylor and Foucault on Power and Freedom," Political Studies 37:2 (1989), 260276. DOI: https://doi.org/10.1111/j.1467-9248.1989.tb01482.x

Patton, Paul, "Foucault's Subject of Power," in Political Theory Newsletter 11 (1994), 60-71. URL: https://www.academia.edu/1445766/Foucaults subject of power.

Prozorov, Sergei, Foucault, Freedom and Sovereignty. Aldershot: Ashgate, 2007.

Rorty, Richard, "Moral Identity and Private Autonomy," in Michel Foucault Philosopher, ed. François Ewald, translated by Timothy J. Armstrong: 328-335. Hemel Hempstead: Harvester Wheatsheaf, 1992.

Schubert, Karsten, Freiheit als Kritik. Sozialphilosophie nach Foucault. Bielefeld: transcript Verlag, 2018.

Sorrentino, Vincenzo, Il pensiero politico di Foucault. Roma: Meltemi, 2008.

Taylor, Charles, "Foucault on Freedom and Truth," in Foucault: A Critical Reader, ed. David C. Hoy, 69-102. Malden: Blackwell, 1986.

Tiisala, Tuomo, "Overcoming 'the Present Limits of the Necessary': Foucault's Conception of a Critique," Southern Journal of Philosophy 55, no. S1, Spindel Supplement (2017), 7-24. DOI: https://doi.org/10.1111/sjp.12224

Vogelmann, Frieder, "Critique as a Practice of Prefigurative Emancipation," Distinktion: Journal of Social Theory 18:2 (2017), 196-214. DOI: https://doi.org/10.1080/1600910X.2017.1358645

Vogelmann, Frieder, "Review of For Foucault: Against Normative Political Theory, by Mark G. E. Kelly," Notre Dame Philosophical Reviews. An Electronic Journal, 2018 (accessed October 5, 2018). URL: https://ndpr.nd.edu/news/for-foucault-against-normative-political-theory/

Walzer, Michael, “The Politics of Michel Foucault," in Foucault: A Critical Reader, ed. David C. Hoy, 51-68. Malden: Blackwell, 1986. 


\section{Acknowledgement}

I would like to thank Timo Jütten, Johanna Oksala, and Peter Dews for reading and commenting earlier drafts of this paper.

\section{Author info}

Dr. Giovanni Maria Mascaretti Department of Politics and International Relations University of Kurdistan Hewlêr Kurdistan Region, Iraq giovanni.mascaretti@ukh.edu.krd

Giovanni Maria Mascaretti received his PhD in Philosophy from the University of Essex (UK) in 2017. He is now Lecturer in Political Theory, Research Methodology, and International Relations in the Department of Politics and International Relations of the University of Kurdistan Hewlêr.

Disclosure Statement: No potential conflict of interest was reported by the author. 